\title{
SPHECID WASPS OF THE WORLD
}

A GENERIC REVISION 


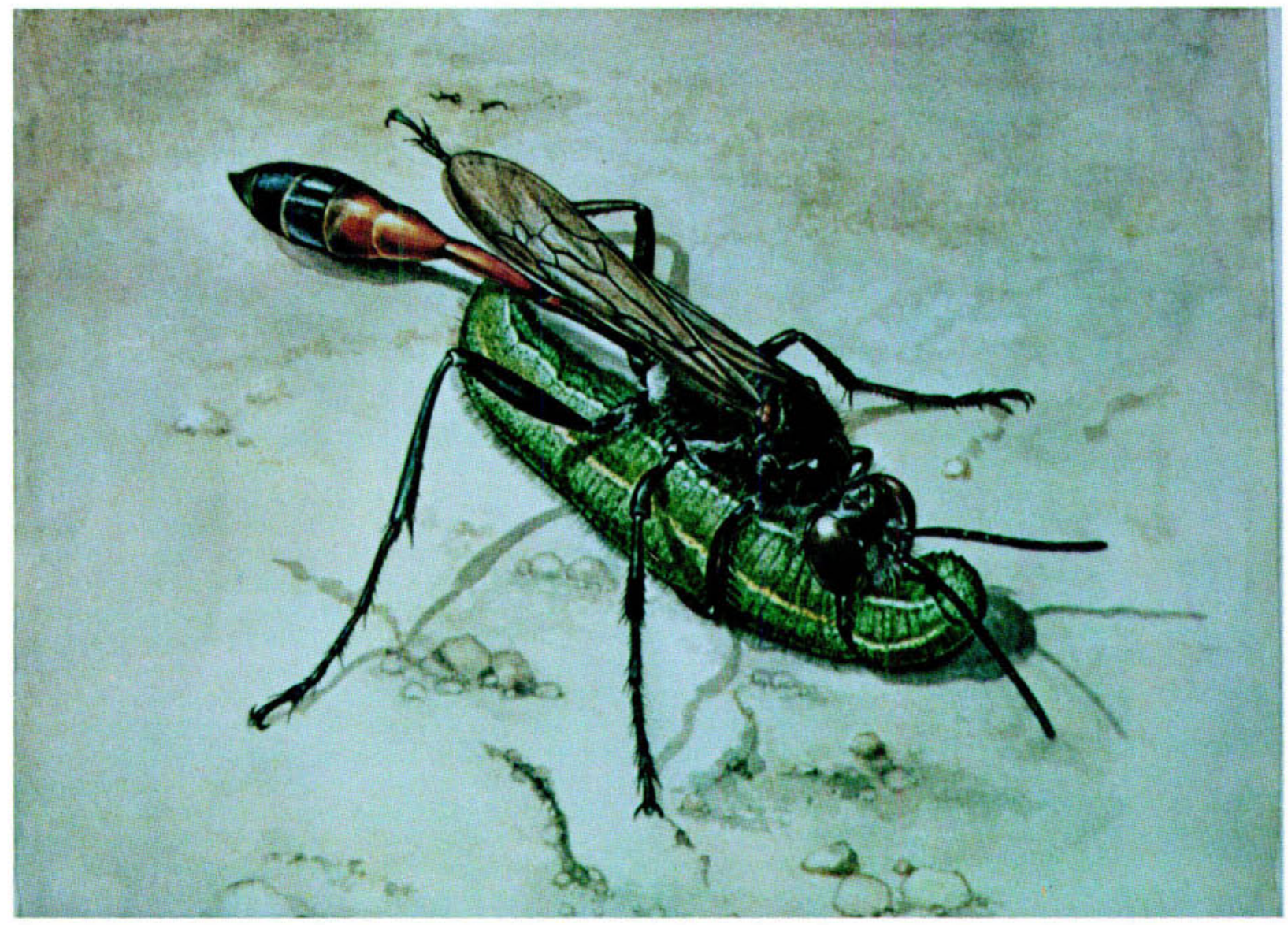

Ammophila azteca Cameron and its prey, the alfalfa caterpillar, Colias eurytheme Boisduval. 


\section{SPHECID WASPS}

OF THE WORLD

A G E N E R I C R E V I S I O N

R.M.BOHART and A.S.MENKE

in collaboration with

H.S.COURT, F.D.PARKER, E.E.GRISSELL, and D.P.LEVIN

UNIVERSITY OF CALIFORNIA PRESS

BERKELEY - LOS ANGELES - LONDON 
Issued June 25, 1976

University of California Press

Berkeley and Los Angeles, California

University of California Press, Ltd.

London, England

Copyright $\odot 1976$, by

The Regents of the University of California

ISBN 0-520-02318-8

Library of Congress Catalog Card Number: 72-87207

Printed in the United States of America 